\title{
Contemporary Leadership Theories: Humanistic Perspective
}

\section{Сучасні теорії лідерства: гуманістичний ракурс}

\author{
Mariia Vyzhva \\ Postgraduate Student, Department of Psychology of National \\ Pedagogical Dragomanov University, Kyiv (Ukraine) \\ ORCID ID: https://orcid.org/0000-0003-4596-4164 \\ E-mail: mariacherpack@gmail.com
}

\section{Марія Вижва}

Аспірантка кафедри психології, Національний педагогічний університет імені М. П. Драгоманова, м. Київ (Україна)

\section{ABSTRACT}

Basic concepts of leadership that emerged in the late XX-early XXI centuries are analyzed in the article. The role and position of a leader in accordance with the team he / she leads is examined. The aim of the article is to identify theoretical aspects of the leadership phenomenon. To identify the peculiarities of the phenomenon, special attention is paid to the theories of humanistic direction.

In the realization of the purpose of this article the theoretical methods of research were used: analysis of psychological literature; systematization, generalization, structuring of data of theoretical concepts.

The results of the research suggest that it has been determined that effective leader mediates between the organization and the individual in order to ensure the achievements of the company and meet the needs of the individual in growth and self-development (C. Argyris), demonstrate empathy, attentiveness

Address for correspondence, e-mail: kpnu_lab_ps@ukr.net Copyright: (C) Vyzhva Mariia

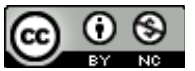


DOI: https://doi.org/10.32626/2227-6246.2020-47 2020. випуск 47 in the perception of new information, the ability to respond to it and depends on the development of emotional intelligence (D. Goleman, R. Boyatzis, A. McKee), care for needs of his followers, serve them and help in achieving individual and team goals ( $R$. Greenleaf). It has been researched that Uniqueness, authenticity, leadership presence are the keys to successful leadership in the model by J. Scouller. These qualities of a leader are also underlined by B. George and S. Friedman.

As a conclusion the necessity of conducting empirical research to observe advantages of contemporary leadership theories are noted and the importance of determining peculiarities of leadership qualities development in schoolchildren are stated.

Key words: leadership, leadership theories, humanistic leadership theories, servant leadership, resonant leadership, authentic leadership, emotional intelligence, total leadership.

\section{Вступ}

В умовах зростаючої невизначеності сучасне українське суспільство потребує людей, готових не лише брати на себе відповідальність, а й таких, які зможуть у цих умовах передбачати, критично оцінювати, знаходити креативні рішення, створювати партнерські стосунки, досягати високих результатів у команді тощо. Модернізація освіти, армії, економіки країни призводить до змін у вимогах до лідера. У зв'язку з цим важливого значення набуває вивчення лідерства і як соціально-психологічного феномену, й у ракурсі індивідуальних психологічних лідерських властивостей із метою визначення особливостей їх становлення та розвитку в особистості.

У зарубіжній психології феномен лідерства досліджували і продовжують розвивати його ідеї Б. Аволіо та Б. Басс (Bass \& Avolio, 1994), Дж. Антонакіс і Д. Убанкс (Antonakis \& Eubanks, 2017), К. Арджиріс (Argirys, 1990), Р. Блейк і Дж. Моутон (Blake \& Mouton, 1982), Дж. Гарднер (Gardner, 1989), Р. Грінліф (Greenleaf, 1970), Б. Джордж (George, 2003), Д. Мак-Грегор (McGregor, 1966), Дж. Скул(C) Vyzhva Mariia

DOI (article): https://doi.org/10.32626/2227-6246.2020-47.09-26 
лер (Scouller, 2016), Ф. Фідлер (Fiedler, 1972), С. Фрідмен (Friedman, 2014) та ін.

У ранніх дослідженнях феномену лідерства (XX ст.), як правило, спостерігаються підходи, зорієнтовані на лідера як представника позиційної влади. Цей феномен розглядався переважно в організаційних або управлінських контекстах, а тому основні напрями досліджень стосувалися визначення способів досягнення мети управлінцем і необхідних рис характеру лідера, які сприяють цьому процесу i допомагають позиційному лідеру впливати на колектив організації (Bass \& Strogdill, 1990). Ці теорії відображають традиційні на той час уявлення про лідерство, що характеризується мускулінними, індустріальними та структурними підходами.

Для досліджень другої половини XX ст. характерно зміщення фокусу уваги на визначення лідерства з точки зору його ролі у процесі виробництва, розглядаючи не тільки представників позиційної влади, а й роль послідовників у процесі управління. Учені все ще звертали увагу на позиційні ролі, проте уже почали визнавати, що результати досягнень часто залежать не лише від якостей особистості лідера, але й від того, як він може мобілізувати, мотивувати й іншим чином впливати на продуктивність послідовників, сприяючи i ïx особистим досягненням, i зростанню. Так, лідерство поступово стало синонімом ефективного управління та гуманістичного впливу на співробітників (Posner, Kouzes \& Barry, 2003).

Основним підгрунтям для таких ідей у теорії лідерства стали популярні на той час гуманістичні напрями у психології, які розглядають особистість як унікальну цілісну систему, здатну і відкриту до саморозвитку, самоактуалізації, що дає змогу їй самій обирати і спрямовувати свою долю (А. Маслоу (Maslow, 1954), Р. Мей (Мay, 1967), К. Роджерс (Rogers, 1951), В. Франкл (Frankl, 2011) та ін.). Представники гуманістичного підходу щодо феномену лідерства (К. Ар-

(C) Vyzhva Mariia

DOI (article): https://doi.org/10.32626/2227-6246.2020-47.09-26 
джиріс (Argirys, 1990), Р. Блейк і Дж. Моутон (Blake \& Mouton, 1982), Р. Лайкерт (Likert, 1961), Д. Мак-Грегор (McGregor, 1966) вважають, що лідер повинен змінити організацію таким чином, щоб кожен індивід мав свободу для забезпечення його власних цілей і потреб, які не лише не нашкодять цілям організації, а, навпаки, - сприятимуть їі розвитку.

У межах окресленого напряму почали розвиватися: інтеграційна теорія індивіда й організації (К. Арджиріс (Argirys, 1990); теорія емоційного лідерства (Д. Гоулмен, Р. Боятіз, Е. Маккі (Goleman, Boyatzis \& McKee, 2013); концепція лідерства-служіння (Р. Грінліф (Greenleaf, 1970); інтеграційна психологічна теорія (Дж. Скуллер (Scouller, 2016); концепція автентичного лідерства (Б. Джордж (George, 2003); теорія тотального лідерства (С. Фрідмен (Freidman, 2014) тощо. Акцент у цих розробках автори ставлять на важливості турботи лідерів про своїх послідовників.

Мета статті - проаналізувати сучасні концепції лідерства та визначити психологічні особливості цього феномену в теоріях гуманістичного спрямування.

\section{Завдання статті}

1. Проаналізувати визначення феномену лідерства.

2. Описати основні компоненти сучасних теорій лідерства та здійснити їх порівняльний аналіз.

3. Визначити необхідні лідерські якості та здібності відповідно до авторів концепцій.

\section{Методи та методики дослідження}

Для реалізації мети статті використано теоретичні методи дослідження, а саме: аналіз психологічної літератури, систематизація, узагальнення, структурування даних теоретичної концепції для прикладного використання. 


\section{Результати та дискусії}

К. Арджиріс, автор інтеграційної теорії індивіда й організації, досліджував концепцію організаційного навчання та його вплив на зростання компанії, їі ефективність і адаптивність. Учений стверджує, що відкрите спілкування в організації, як правило, вважається хорошою ознакою, але може блокувати навчання і перешкоджати прогресу, якщо воно засноване на обороні, запереченні реальних проблем, нездатності розв'язувати складні проблеми і відмові від власних поглядів (Argirys, 1990: 89).

Ним уведено поняття континууму незрілості-зрілості, яке розкриває можливості успішного розширення прав та ініціатив працівника, і вимагає від керівництва забезпечення умов для особистісного зростання співробітників у таких напрямах: від пасивності до діяльності; від залежності до незалежності; від низького рівня прояву до високого; від дрібних інтересів до глибоких; від короткострокової перспективи до довгострокової; від підпорядкування до рівності; від відсутності самоусвідомлення до самоконтролю. К. Арджиріс вважав, що природа компанії полягає у контролі й організації індивідів для досягнення цілей бізнесу, а природа індивіда полягає у прагненні свободи та задоволенні власних потреб за допомогою ініціативи і відповідальності. У такій ситуації завдання ефективного лідера - бути посередником між організацією й індивідом, забезпечувати досягнення результатів компанії та задоволення потреб індивіда у зростанні та саморозвитку (Argirys, 1994: 120).

Взаємодія між співробітниками та лідерами, їх взаємний вплив один на одного розглядаються у трансакційній i трансформаційній теоріях, теорії обміну, "командному лідерстві», «лідерстві у співпраці». Ці теорії започатковані ще у 1970-х рр., проте активно розвиваються і зараз. Їх поєднують уявлення про лідера як про людину, яка відчуває потреби та бажання послідовників. Предметом аналізу в них стає

(C) Vyzhva Mariia

DOI (article): https://doi.org/10.32626/2227-6246.2020-47.09-26 
стиль лідерства та міжособистісні стосунки у команді, що утруднено без розвиненого емоційного інтелекту, над питаннями ролі якого у лідерстві працювали Б. Басс (Bass, 1985), Ф. Дансерау (Dansereau et al., 1975), С. Хілл (Hill, 1982), К. Пірс, Дж. Конгер, Е. Лок (Pearce, Konger \& Locke, 2008), Д. Гоулмен, Р. Боятіз, Е. Маккі (Goleman, Boyatzis \& McKee, 2013), Р. Грінліф (Greenleaf, 1970) та ін.

Е. Маккі та Р. Боятіз, працюючи над ідеєю резонансного лідерства, визначили, що лідери, які пробуджують у послідовників сильні емоції та надихають їх завдяки своєму позитивному ставленню і ясному баченню, працюють із командою ефективніше й отримують вищі результати. Розвивається ця резонансність завдяки демонстрації співпереживання, уважності при сприйнятті нової інформації, а також умінню відповідно реагувати на неї. На думку авторів, усі лідери володіють такою здатністю, однак саме рівень емоційного інтелекту визначає їх здібність до управління почуттями й емоціями, які мотивують команди до досягнення мети (Boyatzis \& McKee, 2005).

У співпраці з Д. Гоулменом Е. Маккі та Р. Боятіз продовжили розвивати цю концепцію і розробили теорію емоційного лідерства (оригінальна назва - primary leadership, тобто «першочергове» лідерство). Автори стверджують, що «фундаментальним завданням лідера є розпалення (to prime) позитивних почуттів у тих, кого він веде. Це відбувається, коли лідер створює резонанс - резервуар позитивності, який вивільняє у людях найкраще» (Goleman, Boyatzis \& McKeе, 2013: 3). Учені переконані, що найголовніше для лідера - здатність залучати та спрямовувати емоції своїх послідовників, змінюючи їх у позитивний бік, справляючись із негативними. Отже, саме емоційний інтелект стає запорукою успіху лідера. Д. Гоулмен, Р. Боятіз і Е. Маккі провели низку досліджень, які показують пряму кореляцію між позитивними емоціями та високими результатами діяльності організації.

(C) Vyzhva Mariia

DOI (article): https://doi.org/10.32626/2227-6246.2020-47.09-26 
Проте, резонансне лідерство не обмежується лише використанням позитивних емоцій, а й передбачає використання лідером емпатії, яка дає змогу поєднуватися з іншими на емоційному рівні таким чином, що вони почувають себе захищеними. Така взаємодія допомагає створювати тривалі позитивні почуття у послідовників, що, зрештою, сприяє підвищенню продуктивності. Дисонанс, навпаки, активує такі почуття, як злість і страх, через які інші негативні емоціï тривалий час панують у колективі (Goleman, Boyatzis \& McKee, 2013).

На основі зазначеної теорії автори виокремлюють шість стилів лідерства, чотири з яких відповідають принципам резонансного лідерства, а два - дисонансного. Резонансними стилями лідерства є: лідерство бачення (цей стиль дає змогу надихати інших на інноваційність і розробку нового бачення для майбутнього); коучингове лідерство (спілкування сам на сам із послідовниками, визначаючи їх власні цілі та способи їх досягнення під час роботи в організації); афіляційне лідерство (акцент на особистісних стосунках у команді, увага до емоційних потреб послідовників); демократичне лідерство (вироблення спільних рішень у команді та демонстрація цінності кожного). Дисонансні стилі включать моделювання темпу (очікування та заохочення відмінного результату від високомотивованих і цілеспрямованих послідовників) і командування (є ефективним у надзвичайних ситуаціях та у часи невизначеності) (Goleman, Boyatzis \& McKee, 2013: 55). Незважаючи на можливості досягнень команди у разі застосування останніх двох стилів, вони здійснюють токсичний ефект на атмосферу в колективі, якщо використовуються досить часто. Автори стверджують, що більшість людей схильні обирати певний стиль і використовувати його постійно. Однак важливо знати про існування й інших стилів і практикувати їх у відповідних ситуаціях.

Гуманізм і важливість турботи щодо своїх послідовників містить концепція лідерства-служіння, розроблена Р. Грін-

(C) Vyzhva Mariia

DOI (article): https://doi.org/10.32626/2227-6246.2020-47.09-26 
ліфом. Він адаптував працю Тао Те Чінг, написану тисячі років тому, та додав основній концепції сучасних рис. Відповідно до цієї теорії лідер повинен, перш за все, служити людям, тобто піклуватися, щоб їх потреби були задоволені. Лідер-слуга не вважає себе вищим за тих, кого він веде. Швидше за все, він є першим серед рівних і готовий вести за собою інших, щоб досягти узгодженої мети. Йому не властива статусна позиція лідера, яка сама по собі робить його кращим, ніж інші. Тому він постійно працюе над розвитком команди. Такий лідер опиратиметься на сильні сторони послідовників, дозволятиме кожному робити те, що він робить найкраще, а не вестиме за собою команду, використовуючи лише накази (Greenleaf, 1970). Така позиція лідера, на думку Р. Грінліфа, дає змогу його послідовникам зростати, досягати спільно поставленої мети і створювати умови, у яких кожен може виявляти себе як лідер.

Перелік особистісних якостей та умінь лідера у цій концепції включає: уміння слухати та розуміти інших; прийняття й емпатію; уміння аналізувати ситуацію та передбачати проблеми; усвідомленість і проникливість; уміння переконувати й організовувати інших. На думку Р. Грінліфа, справжні лідери - гарні співрозмовники, готові до інноваційних і креативних рішень, а також першими ініціюють зміни, орієнтовані на досягнення мети (Greenleaf, 1970). Такі дослідники лідерства, як С. Кові (Covey, 1989), Т. Серджіовані (Sergiovanni, 1992), Л. Спipc (Spiers, 2010), P. Хейфец (Heifetz, 1998), також визначають окреслені характеристики як важливі компоненти ефективного лідерства. Останні дослідження у галузі поведінкової економіки доводять, що команда отримує переваги, якщо працює з урахуванням ідей лідерства служіння (Манго, 2018). Ідеї Р. Грінліфа набули широкого розповсюдження в американському суспільстві та продовжують розвиватися у Свропі та пострадянських країнах. Так, його ідеї використовували та продовжують застосовувати у своїй практиці M. ді Прі (De (c) Vyzhva Mariia

DOI (article): https://doi.org/10.32626/2227-6246.2020-47.09-26 
Pree, 1987), У. Беніс (Bennis, 2007), Л. Спірс (Spiers, 2010), К. Kic (Keith, 2012), Д. Фрік (Frick, 2013) та ін.

Філософія лідерства служіння знайшла своє місце і в сучасній трирівневій моделі лідерства Дж. Скуллера. Зазначена теорія об'єднує класичні теорії (усуваючи їх недоліки), звертає увагу на психологію лідера та впроваджує ідею про те, що лідер повинен піклуватися про задоволення потреб своїх послідовників, так само як і стосовно своїх власних (Scouller, 2016). Дж. Скуллер вважає, що лідер працює разом з іншими і для них, а не навпаки. Лідеру важливо пам'ятати, що усі члени команди є важливими i ïx думки заслуговують на увагу. Саме таке ставлення дозволяє демонструвати акт служіння іншим. У зв'язку з цим автор наголошує на таких аспектах лідерства, як взаємозалежність, визнання, піклування та баланс (Scouller, 2016).

Ключовим елементом трирівневої моделі Дж. Скуллера $\epsilon$ феномен лідерської присутності (leadership presence), того, як лідер проявляє свою автентичність, демонструє повагу й увагу до інших, говорить чесно та відкрито, демонструючи власний унікальний характер. Лідер повинен володіти професійними прийомами та методами, щоб впливати на інших, проте саме його унікальна, щира «присутність» і надихає інших, викликає повагу і довіру та спонукає обирати своїм лідером (Scouller, 2016: 94).

Автентична «присутність» кожного - унікальна і визначається сімома характеристиками: особистісна сила (уміння управляти думками й емоціями); висока, проте адекватна самооцінка; прагнення до зростання; відповідальність і бажання служіння суспільству, повага до свободи вибору особистості; інтуїція; уміння перебувати «тут і тепер»; внутрішній спокій і почуття наповненості. На думку Дж. Скуллера, «лідерську присутність» можна розвивати, практикуючи індивідуальне лідерство (Scouller, 2016).

Отже, Дж. Скуллер, інтегруючи класичні теорії лідерства, усуваючи їх недоліки, розробив нову модель, що змі(C) Vyzhva Mariia DOI (article): https://doi.org/10.32626/2227-6246.2020-47.09-26 
щує увагу на особистісні характеристики та компетентності лідера, його навички роботи у команді та з їі членами, а також обізнаність щодо психологічних технік і прийомів організації команди. Однак, особливу увагу автор приділяє унікальності й індивідуальності особистості лідера та підкреслює важливість індивідуального розвитку всіх членів колективу, де кожен може виявити себе лідером у команді.

Інша сучасна концепція лідерства, що грунтується на принципах гуманістичної психології, - концепція автентичного лідерства Б. Джорджа. На думку автора, більшість теорій лідерства звертають увагу лише на стилі лідерства, які базуються на певних рисах і якостях лідера, що призводить до втрати особистості й індивідуальності. У своєму прагненні отримати прихильність послідовників і досягти фінансових результатів формальні лідери великих корпорацій і політичні лідери зловживають використанням готових рецептів успіху, забуваючи про власні цінності та погляди (George, 2003).

Б. Джордж вважає, що світ потребує автентичних лідерів, щирих і відданих побудові довготривалих організацій. Такі лідери мають чітко усвідомлювати власну мету та жити відповідно до своїх ключових цінностей. Першочерговим завданням своїх компаній вони вважають задоволення потреб співробітників та інвесторів, а також визначають важливість служіння суспільству (George, 2003).

На думку Б. Джорджа, автентичними лідерами не народжуються. Маючи певний набір якостей i бажання до саморозвитку, вони працюють над удосконаленням своїх якостей та усвідомленням власних цінностей. Не зважаючи на те, що автентичний лідер піклується про інших і будує довготривалі стосунки, у питаннях моралі та цінностей він є непорушним. Автор не погоджується з ідеями про стиль лідерства та наголошує на важливості особистості й унікальності кожного, хто прагне лідерства. «Щоб бути аутентичним, кожен із нас має розвинути свій власний стиль лідер(C) Vyzhva Mariia

DOI (article): https://doi.org/10.32626/2227-6246.2020-47.09-26 
ства, який відповідає особистості та характеру. Попри концепції, які можна зустріти у більшості джерел із лідерства, ваш стиль не має значення. Визначні лідери світу - Дж. Вашингтон, А. Лінкольн, В. Черчіль, Ф. Рузвельт, М. Тетчер, М. Л. Кінг - мали різні стилі, проте усі вони були автентичними. Намагаючись наслідувати їх, ви приречені виглядати смішно» (George, 2003: 12). Для того, щоб вдало пристосовуватися до реалій сьогодення, лідери повинні уміти адаптуватися до змін навколишнього середовища, а також розуміти потреби оточуючих і бачити найефективніші способи взаємодії. Однак обрана тактика не може суперечити особистості лідера та його ключовим цінностям.

У своїй праці «Автентичне лідерство» Б. Джордж визначає найголовніші якості справжнього лідера: розуміння власної мети, практика ключових цінностей, емоційне лідерство, утвердження стосунків, демонстрація самодисципліни. Відповідно до цих якостей лідерам необхідно розвивати відданість і захоплення власною метою (мотивація), демонструвати власною поведінкою свої цінності, співчувати та проявляти емпатію, працювати над уміннями налагоджувати й підтримувати стосунки з іншими, протистояти перешкодам у стресових ситуаціях і бути завжди готовими до змін. Аутентичне лідерство пояснюється як патерни поведінки, через які лідер демонструє компоненти аутентичного лідерства. Отже, для лідера недостатньо практикувати самоусвідомленість та інші необхідні риси без щирості у своїх діях і переконаннях (George, 2003).

Поєднання таких важливих характеристик лідера, як високий емоційний інтелект й автентичність, дали підстави американському досліднику С. Фрідмену розробити концепцію «тотального» («досконалого») лідерства (оригінальна назва - total leadership), ключовим елементом якої є прагнення лідера до цілісності й інтеграції усіх сфер діяльності. Концепція С. Фрідмена базується на трьох головних принципах-рекомендаціях для лідерів: 1) бути справжнім

(C) Vyzhva Mariia

DOI (article): https://doi.org/10.32626/2227-6246.2020-47.09-26 
(аутентична поведінка 3 проясненням важливих моментів); 2) бути цілісним (поводитися чесно, поважаючи кожну людину); 3) бути інноваційним (використовувати та розвивати креативність у щоденній діяльності) (Friedman, 2014). Усі ці якості можна розвивати.

Автор стверджує, що лідерство у бізнесі не може стосуватися лише бізнесу, воно повинно втілюватися на чотирьох рівнях: робота, сім'я, громада й індивідуальність. Підхід С. Фрідмена був перевірений на заводі «Форд» та у Вортонскому інституті університету Пенсильванії. Він передбачає ідею про те, що лідерство має втілюватися на усіх рівнях організаційної культури, щоб створювати стійкі зміни в компанії. Воно повинно виходити за межі професійної сфери і сприяти встановленню балансу між роботою та особистим життям людини (Friedman, 2014). Аналіз досвіду впровадження цієї концепції у громадських організаціях і корпораціях США, Канади, Свропи, Центральної Африки та Південної Америки показав, що зниження стресу, потоку кадрів і прогулів сприяє підвищенню продуктивності співробітників та організації загалом.

\section{Висновки}

У XXI ст. посилився зв'язок між філософією лідерства служіння та сучасними теоріями лідерства. Останні намагаються інтегрувати переваги традиційних теорій, урахувати всі сторони та рівні діяльності лідера, а також звертають увагу на зміну позиції лідера у колективі від формально статусної (позиційно владної) до неформально гнучкої (аутентичної) відповідно до світових реалій сьогодення. На часі виявилися актуальними раніше вже впроваджувані у теорію лідерства ідеї гуманістичної психології про розвиток, потребу в саморозвитку та самореалізації особистості. Сучасне їх звучання визначилося акцентом на здатності лідера бути резонансним, щирим, відкритим у стосунках, аутентичним, унікальним, прагнути служіння справі, ідеї, власним по(c) Vyzhva Mariia

DOI (article): https://doi.org/10.32626/2227-6246.2020-47.09-26 
слідовникам. Лідер повинен бути добре усвідомленим щодо власних особистісних якостей і властивостей, здійснювати їх розвиток. При цьому його увага до зовнішнього середовища, колективу людей, керівництво якими він здійснює, не повинна обмежуватися використанням їх наявного ресурсу, а має бути з передбаченням їх розвитку, стимуляцією, мотивацією до саморозвитку. Ще однією особливістю сучасних теорій є вихід лідерства за межі певної сфери (бізнес, освіта, публічна сфера) та необхідність інтеграції цього процесу в інші сфери життєдіяльності, як-то сім'я, відпочинок, саморозвиток тощо.

Більшість концепцій із порушеної тематики залишаються досить узагальненими, а тому потребують розвитку та досліджень щодо їх ефективності. Перспективним напрямом нашого дослідження буде емпіричне визначення особливостей становлення у школярів тих лідерських властивостей, що складають структуру сучасного образу ефективного лідера.

\section{References}

Antonakis, J., \& Eubanks, D. L. (2017). Looking Leadership in the Face. Current Directions in Psychological Science, 26, 270-275.

Argyris, C. (1990). Integrating the Individual and the Organization. New York : Routledge.

Argyris, C., \& Schön, D. (1974). Theory in practice: increasing professional effectiveness. San-Francisco, California : Jossey-Bass Publishers.

Bass, B. M. (1985). Leadership and performance beyond expectations. New York : The Free Press.

Bass, B. M., \& Avolio, B. J. (Eds.). (1994). Improving organizational effectiveness through transformational leadership. Thousand Oaks, CA : Sage Publications.

Bass, B. M., \& Stogdill, R. M. (1990). Bass \& Stogdill's Handbook of Leadership: Theory, Research, and Managerial Applications. New York : Free Press.

Bennis, W., \& Thomas, R. (2007). Leading for a Lifetime: How Defining Moments Shape Leaders of Today and Tomorrow. Boston, Massachusetts : Harvard Business Review Press.

(C) Vyzhva Mariia

DOI (article): https://doi.org/10.32626/2227-6246.2020-47.09-26 
Blake, R. R., \& Mouton, J. S. (1982). Theory and Research for Developing a Science of Leadership. The Journal of Applied Behavioral Science, 18 (3), 275-291.

Boyatzis, R., \& McKee, A. (2005). Resonant Leadership: Renewing Yourself and Connecting with Others Through Mindfulness, Hope, and Compassion. Boston, Massachusetts : Harvard Business Review Press.

Covey, S. (1989). The 7 Habits of Highly Effective People. New York : Free Press.

Dansereau, F. Jr., Graen, G. B., \& Haga, W. J. (1975). A Vertical Dyad Linkage Approach to Leadership within Formal Organizations: A Longitudinal Investigation of the Role Making Process. Organizational Behavior and Human Performance, 13, 46-78.

De Pree, M. (1987). Leadership is an Art. East Lansing, MI : Michigan State University Press.

Fiedler, F. E. (1972). The Effects of Leadership Training and Experience: A Contingency Model Interpretation. Administrative Science Quarterly, 17 (4), 453-470.

Frankl, V. (2011). The Unheard Cry for Meaning. Psychotherapy and Humanism. New York : Simon \& Schuster.

Frick, D. (2013). Implementing Servant Leadership: Stories from the Field La Crosse, WI : D. B. Reinhart Institute for Ethics in Leadership.

Friedman, S. D. (2014). Leading the life you want: skills for integrating work and life. Boston, Massachusetts : Harvard Business Review Press.

Gardner, J. (1989). Leadership Development. NASSP Bulletin, 73 (515), 73.

George, B. (2003). Authentic Leadership: Rediscovering the Secrets to Creating Last Value. San-Francisco, California : Jossey-Bass Publisher.

Goleman, D., Boyatzis, R., \& McKee, A. (2013). Primal leadership: Unleashing the power of emotional intelligence. Boston, Massachusetts : Harvard Business Review Press.

Graen, G., \& Uhl-Bien, M. (1995). Relationship-based approach to leadership: Development of leader-member exchange (LMX) theory of leadership over 25 years: Applying a multi-level multi-domain perspective. The Leadership Quarterly, 6 (2), 219-247.

Greenleaf, R. (2008). Servant as a Leader. Atlanta, GA : Greenleaf Center for Servant Leadership.

Heifetz, R. (1998). Leadership Without Easy Answers. Cambridge, MA : Harvard University Press.

Hernez-Broome, G. (2004). Leadership development: Past, present, and future. Retrieved from http://pdfrelease.net/external/1728589/ pdf-release-dot-netleadership \% 20development.pdf.

(C) Vyzhva Mariia

DOI (article): https://doi.org/10.32626/2227-6246.2020-47.09-26 
Hill, S. K. (2010). Team Leadership. Leadership: Theory and Practice. Thousand Oaks, CA : Sage.

Hollander, E. P., \& Julian, J. W. (1969). Contemporary trends in the analysis of leadership processes. Psychological Bulletin, 71 (5), 387397.

Hollander, E. P., \& Julian, J. W. (1970). Studies in Leader Legitimacy, Influence, and Innovation. Advances in Experimental Social Psycho$\log y, 5,33-69$.

Keith, K. (2012). The Case for Servant Leadership. South Orange, NJ : The Center for Servant Leadership.

Kouzes, J. M., \& Posner, B. Z. (2003). The Leadership Challenge. Hoboken, New Jersey : John Wiley \& Sons.

Likert, R. (1961). An Emerging Theory of Organization, Leadership, and Management. Leadership and interpersonal behavior. New York : Holt, Reinhart \& Winston.

Mango, E. (2018). Rethinking Leadership Theories. Open Journal of Leadership, 7, 57-88. Retrieved from https://doi.org/10.4236/ ojl.2018.71005.

Maslow, A. (1954). Motivation and Personality. New York : Harper.

May, R. (1996). Psychology and the Human Dilemma. New York : WW Norton \& Company.

McGregor, D. (1966). Leadership and motivation. Cambridge, MA : M. I. T. Press.

Pearce, C. L., Conger, J. A., \& Locke, A. (2008). Shared leadership theory. The Leadership Quarterly, 19 (5), 622-628.

Rogers, C. (1951). Client-Centered Therapy: Its Current Practice, Implications and Theory. London : Constable.

Rosenbach, W. E. (2018). Contemporary Issues in Leadership. New York, NY : Routledge.

Scouller, J. (2016). The Three Levels of Leadership: How to Develop Your Leadership Presence, Knowhow and Skill. Oxford : Management Books 2000

Sergiovanni, T. J. (1996). Moral Leadership: Getting to the Heart of School Improvement. Hoboken : John Wiley \& Sons.

Spiers, L. (2010). Character and servant leadership: Ten characteristics of effective, caring leaders. The Journal of Virtues \& Leadership, 1, 25-30.

Stogdill, R. M. (1948). Personal factors associated with leadership: A survey of the literature. Journal of Psychology, 25, 35-71.

Uchiyama, K. P., \& Wolf, S. A. (2002). The Best Way to Lead Them. Educational Leadership, 59 (8), 80-83.

(C) Vyzhva Mariia

DOI (article): https://doi.org/10.32626/2227-6246.2020-47.09-26 
Watt, W. M. (2009). Facilitative social change leadership theory: 10 recommendations toward effective leadership. Retrieved from http:// leadershipeducators.org/Resources/Documents/jole/2009_fall/ Watt.pdf.

Winkler, I. (2010). Contemporary Leadership Theories: Enhancing the Understanding of the Complexity, Subjectivity and Dynamic of Leadership. Berlin, Germany : Physica-Verlag Heidelberg.

Yukl, G. (1999). An evaluation of conceptual weaknesses in transformational and charismatic leadership theories. The Leadership Quarter$l y, 10(2), 285-305$.

\section{Вижва Марія. Сучасні теорії лідерства: гуманістичний ракурс}

\section{АНОТАЦІЯ}

У статті проаналізовано основні концепції лідерства, що виникли наприкінці XX - на початку XXI cm., і визначено роль і позицію лідера відповідно до колективу, який він очолює. Мета дослідження полягає у визначенні теоретичних аспектів феномену лідерства. Для визначення особливостей феномену особливу увагу приділено теоріям гуманістичного спрямування, оскільки ідеологи концепцій лідерства почали визнавати, що результати досягнень усе більще залежать не стільки від якостей особистості самого лідера, скільки від того, як він мотивує, впливає на продуктивність послідовників, сприяє їх особистим досягненням і зростанню.

Для реалізації мети нашої статті використано теоретичні методи дослідження, а саме: аналіз психологічної літератури, систематизація, узагальнення, структурування даних теоретичних концепцій.

у статmі розглянуто інтеграційну теорію індивіда й організації К. Арджиріса, теорію емоційного лідерства Д. Гоулмена, Е. Маккі та P. Боятіза, фрілософію лідерства-служіння Р. Грінліфа, модель лідерства Дж. Скуллера, теорію автентичного лідерства Б. Джорджа, теорію тотального лідерства С. Фрідмена.

За результатами дослідження визначено, що у концепції К. Арджиріса завданням ефективного лідера постає посередництво між організацією й індивідом для забезпечення досягнень компанії та задоволення потреб індивіда у зростанні та саморозвитку. 3'ясовано, що ефективність лідера Е. Маккі та Р. Боятіз визначають здатністю до резонансності, що виявляється у демонстрації співпереживання, уважності при сприйнятті нової інформації, умінні відповідно реагувати на неї та залежить (C) Vyzhva Mariia

DOI (article): https://doi.org/10.32626/2227-6246.2020-47.09-26 
від розвитку емочійного інтелекту. Визначено, що філософія лідерства-служіння (Р. Грінліф) висуває до лідера вимогу служіння, піклування про потреби послідовників і членів команди для реалізації мети і позбавляє статусних переваг кращості. Показано, що унікальність, автентичність, щира присутність - основа успішного лідерства у моделі Дж. Скуллера. Ці переваги лідера підкреслено також Б. Джорджем і С. Фрідменом.

Як висновок зазначено необхідність емпіричного дослідження переваг сучасних теорій лідерства та визначення особливостей становлення лідерських властивостей у школярів.

Ключові слова: лідерство, теорії лідерства, гуманістичні теорії лідерства, лідерство служіння, резонансне лідерство, аутентичне лідерство, емоційний інтелект, тотальне лідерство.

\section{Выжва Мария. Современные теории лидерства: гуманистический ракурс}

\section{АННОТАЦИЯ}

В статье проанализированы основные концепции лидерства, которые возникли в конце XX - в начале XXI вв., и определены роль и позиция лидера в коллективе. Цель исследования заключается в определении теоретических аспектов феномена лидерства. Для определения особенностей феномена особое внимание уделяется теориям гуманистического направления, поскольку идеологи концепций лидерства начали признавать, что результаты достижений все больше зависят не столько от качеств личности самого лидера, сколько от того, как он мотивирует, влияет на производительность последователей, способствует их личным достижениям и росту.

Для реализации цели нашей статьи использованы теоретические методы исследования, а именно: анализ психологической литературы, систематизация, обобщение, структурирование данных теоретических концепций.

В статье рассмотрены интеграционная теория индивида и организации К. Арджириса, теория эмоционального лидерства Д. Гоулмена, Э. Макки и Р. Боятиза, философия лидерства-служения Р. Гринлифра, модель лидерства Дж. Скуллера, теория аутентичного лидерства Б. Джорджа, теория тотального лидерства С. Фридмена.

(C) Vyzhva Mariia

DOI (article): https://doi.org/10.32626/2227-6246.2020-47.09-26 
DOI: https://doi.org/10.32626/2227-6246.2020-47

По результатам работы доказано, что в концепции К. Арджириса задачей эффективного лидера становится посредничество между организачией и индивидом для обеспечения достижений компании и удовлетворение потребностей индивида в росте и саморазвитии. Установлено, что эфрфективность лидера Э. Макки и Р. Боятиз определяют способностью к резонансности, что проявляется в демонстрации сопереживания, внимательности при восприятии новой информации, умении соответственно реагировать на нее и зависит от развития эмоционального интеллекта. Определено, что философия лидерства-служения (Р. Гринлиф) ставит к лидеру требование служения, заботы о нуждах последователей и членов команды для реализации цели и лишает статусных преимуществ лучшести. Показано, что уникальность, аутентичность, искреннее присутствие - основа успешного лидерства в модели Дж. Скуллера. Эти преимущества лидера подчеркиваются также Б. Джорджем и С. Фридменом.

Как вывод отмечается необходимость эмпирического исследования предпочтений современных теорий лидерства и определения особенностей становления лидерских свойств у школьников.

Ключевые слова: лидерство, теории лидерства, гуманистические теории лидерства, лидерство служения, резонансное лидерство, аутентичное лидерство, эмоциональный интеллект, тотальное лидерство.

Original manuscript received December 28, 2019

Revised manuscript accepted January 24, 2020

(C) Vyzhva Mariia

DOI (article): https://doi.org/10.32626/2227-6246.2020-47.09-26 http://journals.uran.ua/index.php/2227-6246 